\title{
LA LITERATURA PICARESCA DEL SIGLO XVII ¿UNA NARRATIVA REFORMISTA?
}

La novela picaresca de la primera mitad del siglo xvII difícilmente puede ser comprendida si no se atiende a su situación contextual, ya que se produce en un período de crisis. En este sentido, comparto la idea de Michel Cavillac respecto a que es conveniente restituir esta narrativa "à son historicité qui l'immerge dans la degradation des idéaux aristocratiques et la crise d'un capitalisme marchand victime de sa précocité"1.

Después de haber contado con una economía mercantil próspera en casi todo el siglo XVI, se produjo lo que Pierre Chaunu llama "la inversión de la tendencia” ${ }^{2}$. La situación caótica y deficitaria que atravesaba la corona española, su dependencia acusada de los banqueros genoveses y luego de los portugueses, el "régimen de trampa adelante" ", la proliferación de la mendicidad, una industria nacional pobre y un comercio exterior cada vez más dominado por los extranjeros, la inflación, la desmedida acuñación de moneda de vellón, la disminución demográfica, el auge de la especulación cambiaria y la inversión improductiva, multiplicó, entre 1600 y 1640, la elaboración de obras encaminadas a emprender una reforma general de la sociedad. Las nuevas propuestas económicas, morales y políticas, implicaban un cambio radical que incluía una crítica a los valores del estamento dominante. La picaresca, en su conjunto, se hace portadora de las ideas reformadoras, pues nadie mejor que el pícaro -como el gracioso en el caso del teatro-, carente de valores y compromisos, para censurar los vicios sociales. Esto, desde luego, no significa que asumamos que los autores de dichas novelas fueran reformistas, sino

${ }^{1}$ Gueux et marchands dans le Guzmán de Alfarache (1599-1604), Université de Bordeaux, Bordeaux, 1983 p. 40; véase una idea similar en Michel ZÉRAFfa, Roman et societé, 2 ème ed., PUF, Paris, 1976, p. 12.

2 Sevilla y América. Siglos xV y xVII, Universidad, Sevilla, 1983, p. 269.

${ }^{3}$ RAMÓn CaRAnde, "El crédito de Castilla en el precio de la política imperial", Otros siete estudios de historia de España, Ariel, Barcelona, 1978, p. 59. 
que tales ideas se filtran en los textos manifestando la evolución de las mentalidades en la Península.

La distinción de la nobleza como estamento dominante dependió, en sus orígenes, de su participación militar, de ahí que en las Siete Partidas el honor fuera el resultado de los hechos heroicos y el valor personal. En su lugar surgió una aristocracia cortesana ociosa, cuyo honor se vinculaba al linaje, es decir, a la limpieza de sangre y al recuerdo de las hazañas de los antepasados, y la riqueza. Afirmaciones como la de Juan de Aranda: "en el oro está ya toda la honra", son comunes en la época. De acuerdo con Bernabé Moreno de Vargas, la idea de "no auer más de dos linages en el mundo, que son ricos y pobres..." es muy común. El surgimiento y desarrollo de una economía monetaria trajo como consecuencia que el prestigio social estuviera ligado a la riqueza y, con ello, a un sentido profundo del honor exterior.

El hecho de asumir personalidades postizas nobiliarias, la estafa de honra que se presenta en la narrativa picaresca permite ver este aspecto de la nobleza: Pablos $^{6}$ se hace pasar por caballero; Teresa de Manzanares ${ }^{7}$ se finge hija de un rico capitán, Elena ${ }^{8}$ desempeña el papel de dama para estafar, y de Trapaza se dice: "En cuanto a seguir los modos caballerescos, lo hizo nuestrojoven tan bien con su buen despejo, que, no le conociendo proceder de tan humilde gente, le tuviera cualquiera por un ilustre caballero, procedido de otros tales"9.

Basta, pues, la vestimenta y cierto comportamiento, ambos aspectos externos, para aparentar nobleza. Los bienes son imprescindibles para el linaje y la reputación, de lo contrario se cae en la deshonra: honor y dinero son inseparables. En el Guzmán se expresa:

Mira cuántos buenos están arrinconados, cuántos hábitos de Santiago, Calatrava y Alcántara, cosidos con hilo blanco y otros muchos de la envejecida nobleza de Laín Calvo y Nuño Rasura tropellados. Dime: ¿quién les da la honra a los unos que a los otros quita? El más o menos tener ${ }^{10}$.

${ }^{4}$ Lugares comvnes de conceptos, dichos y sentencias en diuersas materias, Madrid, 1613, f. 165 (BNMadrid, R. 4481).

${ }^{5}$ Discursos de la nobleza de España, Madrid, 1622, f. 49v. (BNMadrid, R. 10994).

${ }^{6}$ Francisco de Quevedo, El Buscón, ed. P. Jauralde Pou, Castalia, Madrid, 1990. En adelante, cito por $E B$, seguido de número de página.

${ }^{7}$ Alonso de Castillo Solórzano, La niña de los embustes, Teresa de Manzanares, en Picaresca femenina, ed. A. Rey Hazas, Plaza \& Janés, Barcelona, 1986. En adelante, $T M$, seguido de número de página.

8 Alonso Jerónimo de Salas Barbadillo, La hija de Celestina, en Picaresca femenina, ed. cit. En adelante, $L h C$, seguido de número de página.

${ }^{9}$ Alonso de Castillo Solórzano, Aventuras del bachiller Trapaza, quinta esencia de embusteros y maestros de embelecadores, en La novela picaresca española, ed. A. Valbuena Prat, Promoción y Ediciones, Madrid, 1980, p. 143. En adelante, AbT, seguido de número de página.

10 Mateo Alemán, Guzmán de Alfarache, ed. S. Gili Gaya, Espasa-Calpe, Madrid, 1971 , t. 2, p. 45 (5 ts.). En adelante, $G A$, seguido de tomo y número de página. 
En La picara Justina se señala "que la codicia de dinero es mondonguera y hace morcillas de sangre de toda broza, por ser toda de un color"11; y concluye: "En resolución, el arancel con que hoy se miden las cualidades y partes humanas es el dinero" (LpJ, p. 448). Amén de que las afirmaciones en este sentido sean numerosas, también encontramos personajes que permiten ver dicha valoración social. Cuatro casos de nobles sin dinero y la actitud de la sociedad son bastante ilustrativos: don Toribio, hidalgo de portante en el Buscón, el Conde de las Legumbres en La garduñ $a^{12}$, don Tomé en Trapaza y Estebanillo González ${ }^{13}$. Dice don Toribio:

Veme aquí vuestra merced un hidalgo hecho y derecho, de casa de solar montañés que si como sustento la nobleza me sustentara, no hubiera más que pedir. Pero ya, señor licenciado, sin pan y carne no se sustenta buena sangre, y por la misericordia de Dios todos la tienen colorada, y no puede ser hijo de algo el que no tiene nada. Ya he caído en la cuenta de las ejecutorias después que, hallándome en ayunas un día, no me quisieron dar sobre ella en un bodegón dos tajadas... He vendido hasta mi sepoltura... sólo el don me ha quedado por vender, y soy tan desgraciado que no hallo nadie con necesidad dél... (EB, p. 173).

Paradójicamente, don Toribio muestra a Pablos cómo engañar, y ambos tienen el mismo paradero, hecho que indica que lo determinante es la situación económica y no la sangre. Aunque el objetivo es el amor, en la segunda novela intercalada en La garduña, don Pedro Ossorio y Toledo, dado que es un pobre segundón, se finge loco y se convierte en bufón de nobles bajo el nombre de Conde de las Legumbres (cf. LgS, pp. 278-303). En Trapaza, don Tomé, un hidalgo venido a menos, se convierte en bufón de una nobleza depravada:

...como es persona de buen humor, de graciosos dichos y razonados donaires, el que le da quiere pagarse y cobrar en gusto lo que ha ofrecido en dinero, y así le han comenzado a perder el respeto y le hacen graciosas burlas cada día y él pasa por ellas por no perder el donativo cotidiano (AbT, p. 234).

La misma aristocracia desdeña y convierte en objeto de burla a nobles sin hacienda, hecho que revela una descomposición axiológica. Estebanillo se mofa de su propia hidalguía y la rechaza por la fal-

11 La pícara Justina, ed. B. Damiani, José Porrúa Turanzas, Madrid, 1982, pp. 103-104. En adelante, $L p J$, seguido de número de página.

12 Alonso de Castillo Solórzano, La garduña de Sevilla y anzuelo de las bolsas, en $L a$ novela picaresca española, ed. cit. En adelante, $L g S$, seguido de número de página.

${ }^{13}$ La vida y hechos de Estebanillo González, hombre de buen humor, compuesta por él mismo, ed. J. Millé y Giménez, Espasa-Calpe, Madrid, 1973, 2 ts. En adelante, EG, seguido de tomo y número de página. 
ta de sustento que implica; decide hacerse pícaro y termina como bufón de grandes. Los cuatro casos se oponen al determinismo de la sangre y a la importancia del linaje, aspectos ideológicos que ceden frente a una sociedad monetaria ${ }^{14}$.

A pesar de la íntima relación del honor con la riqueza -aquél dependía de la limpieza de sangre, pues las mezclas imponían una mancha y en consecuencia la marginación social-; una idea distinta se venía gestando desde la discusión sobre el establecimiento del estatuto de limpieza de sangre ${ }^{15}$. La argumentación de los religiosos contrarios a éste fue la descendencia común, adánica, de los hombres, idea que se desarrolló entre los pensadores reformistas. Así, Sancho de Moncada expresará que "Este rigor vemos en el castigo del pecado de Adán, pues todos los trabajos del mundo son castigo originado de aquel principio"16. El mercader Damián de Olivares, por su parte, sostendrá: "Consideramos que la naturaleza tuvo un principio, y toda generación humana es de una carne y sangre..."17. La idea de un padre común descartaba las diferencias establecidas por la nobleza. Se retoma entonces el pensamiento de san Pablo de que "no hay griego ni judío, circuncisión ni incircuncisión, bárbaro ni escita, siervo ni libre, sino que Cristo es el todo, y en todos" (Colosenses 3: 11). La concepción paulina de la igualdad descartaba las exclusiones raciales y mostraba que la idea aristocrática de que sólo la sangre goda era limpia iba en contra del dogma cristiano. De principio a fin, en La picara Justina hay referencias tanto a la herencia de Adán como a la de Eva: “...el nuestro [principio] fue tierra, polvo y ceniza, obremos como quien teme al que puso al hombre este fin y paradero, y como quien agradece haber salido de tal principio, y como quien ha de volver a Dios, que es universal principio" ( $L p J$, p. 150).

Como vimos, Quevedo alude a que la sangre "por la misericordia de Dios todos la tienen colorada"; en el Guzmán de Luján se señala que por las alcurnias de los hombres "quieren desapriscar a los que Dios juntó en una Iglesia con el retinte de las hazañas de sus antepasados"18; el hombre es polvo y lodo, repite Estebanillo, y considera su hidalguía como herencia del pecado original; que todos son iguales

14 Véase José Antonio Maravall, Estado moderno y mentalidad social, Alianza, Madrid, 1986.

15 Véase Albert Sicroff, Los estatutos de limpieza de sangre, Taurus, Madrid, 1985, p. 135.

16 Restauración política de España, ed. J. Vilar, Instituto de Estudios Fiscales, Madrid, 1974, p. 203.

17 Respuesta de Damián de Olivares a un papel que ha salido sin autor, Madrid, 1622, f. 4 (BNMadrid, VE., 60-12).

18 Mateo Luján, Segunda parte de la vida del pícaro Guzmán de Alfarache, en La novela picaresca española, ed. cit., p. 609. En adelante, $S G A$, seguido de número de página. 
muestra Salas Barbadillo en La hija de Celestina, donde la madre de Elena la vende tres veces: “...la primera a un eclesiástico rico, la segunda a un señor de título, la tercera a un ginovés...” ( $L h C$, p. 164). Luego aparece un mercader judío que también cede a sus pasiones. En el Lazarillo de Manzanares ${ }^{19}$ se sitúan en el mismo nivel el virtuoso hidalgo sevillano y el pícaro quien se pasa a las Indias como su factor. La raza, nacionalidad, ocupación y procedencia social carecen de importancia: todos los hombres son iguales. El origen de Adán también implica una igualdad biológica. Estebanillo, por ejemplo, señala que los caballeros no estimaban sus versos

...porque no eran de poeta con don o descendiente de godos, que también los pobres y humildes saben hacer cosas de ingenio, pues tienen un alma y tres potencias como los más poderosos y cinco sentidos como los más calificados, y que no hay cláusula en el testamento de Adán que dejase, como señor que era entonces de todo el mundo, a los caballeros mejorados en tercio y quinto en las aguas de Hipocrene, y a los pobres, herederos del caño de Bacinguerra; la una fuente del Parnaso con licores poéticos, y el otro caño cordobés con inmundicias selváticas $(E G$, t. 2, p. 107).

En este mismo tenor se habla en La garduña cuando se dice que muchos autores de comedias se niegan a escuchar a cualquier poeta a menos que sea clásico: “...como si Dios que dio ingenio a aquellos que están acreditados con ellos, limitara su poder y no le diera a otros muchos con mucha más claridad" ( $\operatorname{LgS}$, p. 345). La idea de la igualdad proveniente de un principio común, pues, como Michel Cavillac ha demostrado en el Guzmán, también está presente en otras novelas picarescas.

Como vemos, uno de los pilares ideológicos de la nobleza, el linaje, se cuestiona seriamente y ello, a su vez, conduce a poner en tela de juicio la herencia de la virtud. Son innumerables los textos literarios de la época en que se alude a la herencia biológica de la virtud de los nobles. Niños trocados en la cuna revelan inclinaciones de acuerdo con sus orígenes independientemente de la educación recibida: el plebeyo siempre será tal aunque se eduque entre nobles y viceversa, el noble manifestará su virtud a pesar de formarse entre gente viciosa ${ }^{20}$. En El Buscón, Pablos reflexiona: "Más se me ha de

19 Juan Cortés de Tolosa, Lazarillo de Manzanares con otras cinco novelas, ed. G. E. Sansone, Espasa-Calpe, Madrid, 1974, 2 ts. En adelante, $L M$, seguido de tomo y número de página.

${ }^{20}$ Baste citar el caso de Las dos Isabelas de Baltasar Mateo VelázQuez, en El filósofo del aldea, Madrid, s.a., ff. 17 ss. (BNMadrid, R. 19527); o El hayo de su hijo de CASTILlo Solórzano, en Tiempo de regocijo y Carnestolendas de Madrid, Madrid, 1627, f. 141 (BNMadrid, R. 13365), por no recordar La gitanilla. 
agradecer a mí, que no he tenido de quién aprender virtud ni a quién parecer en ella, que al que la hereda de sus agüelos" ( $E B$, p. 143). La igualdad que supone la paternidad colectiva de Adán implicará una valoración de las obras, los méritos de cada uno, como nuevo concepto de nobleza en los pensadores más avanzados del siglo XVII. Hacia 1602 fray Melchor de Huélamo opina que aunque sea plebeyo el hombre virtuoso es noble ${ }^{21}$; Pedro de Rivadeneira, citando a Juvenal, afirma: "Nobilitas sola est atque unica virtus"; y refiriéndose a san Juan Crisóstomo dice: "El que se gloria solamente en la casta de sus padres, da a entender que él de suyo está vacío y sin virtud"22. Damián de Olivares se pregunta "Pues si de la virtud ha nacido la nobleza, por qué la nobleza ha de reprobar y desestimar la misma virtud"23; y Juan de Mariana cuestiona:

¿Confiaríamos nuestra salud y dignidad a varones esforzados y de temple vigoroso por más que sean extranjeros y plebeyos y hayan nacido en un lugar oscuro, o a nobles débiles y afeminados, más notables por la virtud de sus antepasados que por su propio valor ni por sus propios méritos?24.

Con frecuencia leemos en los textos de la época consejos a los príncipes sobre premiar la virtud o dar cargos a quienes los merezcan. Rivadeneira aconseja a los príncipes que no permitan "que los aumentos de los que les sirven estén pendientes de la solícita ambición, sino de sólo los méritos"25. Mateo Luján opina que "el que es amigo de honra hace buenos hechos, y ese es el principio de la nobleza..." (SGA, p. 592); Estebanillo piensa lo mismo cuando señala que la nobleza consiste en ayudar al necesitado "que para no hacer esto, poco me importa a mí ni a nadie que sean grandes o que sean pequeños" ( $E G$, t. 2, p. 229). La propuesta de una nobleza basada en las obras invitaba a modificar la conducta de la aristocracia y posibilitaba que otros grupos tuvieran acceso a ella. Así pues, el reconocimiento del mérito justificaba un ascenso en la escala social y, en algunos casos, una apertura estamental.

El deseo de ascenso es claro en toda la novela picaresca. Castillo Solórzano ve, en Teresa de Manzanares, ese interés en "valer más" como algo virtuoso, y varias veces se refiere a ello. El capitán engañado por Teresa, quien fingió ser su hija, dice al descubrirla: "no me

${ }^{21}$ Libro primero de la vida y milagros del glorioso confessor Sant Ginés de la Xara, Murcia, 1602, f. 127 (BNMadrid, 3-64915).

22 Pedro de Rivadeneira, Tratado de la religión y virtudes, BAE, t. 60, pp. 529 y 531 , respectivamente.

23 Respuesta de Damián de Olivares..., f. 4.

${ }^{24}$ Del Rey y de la Institución Real, BAE, t. 31, p. 541.

25 Op. cit., p. 505. 
admira que un hombre de mediano porte, por sus trazas llegue a verse en mayor altura, que virtud es, cuando no la emprenden con ruines medios" (TM, p. 342). Una idea similar se manifiesta en el Bachiller Trapaza, a quien su abuelo aconseja: "será bien que os ajustéis a tratar más que de estudiar y valer por vuestro ingenio, que de más humildes principios que del vuestro hemos visto levantadas casas por las letras" (AbT, p. 139). Y dice Guzmán: "Cada uno procura de valer más. El señor quiere adelantar sus estados, el caballero su mayorazgo, el mercader su trato, el oficial su oficio y no todas veces con la limpieza que fuera lícito" ( $G A$, t. 4, p. 12). En relación directa con el incremento desmesurado de la mendicidad, Cortés de Tolosa, en el Lazarillo de Manzanares, sostiene:

Ay cosa[s] que aunque son insufribles tienen cierta limitada mejoría, como es un hombre mendigo, hombre, para dezirlo más claro, que capa sobre qué caer muerto no tiene. Éste, quedando necessitado no sólo sino muy necessitado, ¿podrá tener mejoría? Sí, señor, subiendo a pobre, que entonces quiere dezir hombre que tiene, pero limitadíssimamente y con gran aprieto ( $L M$, t. 1, p. 113).

La picaresca critica el ascenso ilícito, por ello Pablos o Guzmán se ven descubiertos y son castigados; por ello Trapaza recibe varias veces terribles lecciones. Las vías para progresar eran las letras, el trabajo en general y, en particular, el comercio.

De esta manera, el reformismo basado en la paternidad colectiva implicaba también una sanción a la ociosidad, debido a que el trabajo nació por el pecado original. Así, sostiene Cellorigo: “...pues el trabajo como ordenado de Dios a los hombres es de tanta nobleza, que jamás dejó de premiar al que le sigue"26. La censura del ocio como destrucción de la monarquía está en pensadores como Sancho de Moncada, Juan de Mariana, Pedro de Rivadeneira, Saavedra Fajardo, y es acusación a quienes hacían de él un modus vivendi. El ocio era una distinción de la nobleza, pues tradicionalmente los moros y los judíos eran quienes se habían dedicado al manejo del dinero y a los oficios mecánicos. En Teresa de Manzanares se dice que los caballeros llevan una vida "regalada y viciosa" que desdora su "noble sangre" (TM, p. 227), pues sus ocupaciones son "los lascivos entretenimientos... que desenfrenadamente corren por ellos, llevados de sus insaciables apetitos, polilla de sus haciendas y saludes" (TM, p. 289). Misma imagen presenta Salas Barbadillo en La hija de Celestina, donde don Sancho es un personaje lascivo, al servicio de sus pasiones. Definida como vicio, la holgazanería era la contraparte de la virtud

26 Memorial de la política necessaria y útil restauración de la República de España, Valladolid, 1600, f. 24 (BNMadrid, VE 207-6). 
que se encontraba en el trabajo. Como Francisco Núñez ${ }^{27}$ hay otros pensadores reformistas que reprueban la ociosidad de la nobleza; Gaspar Gutiérrez de los Ríos prefiere al oficial que al hidalgo ocioso $^{28}$. La promulgación de los estatutos de limpieza de sangre había favorecido un desprecio a las actividades productivas. Según Saavedra Fajardo hasta los plebeyos tenían un espíritu altivo y aspiraban a poseer nobleza ${ }^{29}$. En este sentido opina Sancho de Moncada: "La ociosidad, y holgazanería, es vicio de españoles bien conocido de Extranjeros..." 30; "el trabajo no es honrado, sino el que sigue la holgura y el passeo" 31 . Ante este tipo de prejuicios los pensadores reformistas, retomando la idea paulina, conforman una concepción honrada del trabajo que parte de considerarlo un precepto divino. Así, Pedro de Guzmán sostendrá: "Sin duda quisso nuestro Dios con este modo de dezir, [hagamos al hombre] acreditar... para con el hombre el trabajo de las manos, y que de su misma formación y Autor aprendiesse a ocuparse en el ejercicio dellas" 32 .

En algunas novelas picarescas encontramos una reivindicación del trabajo que siempre implica una crítica a la ociosidad. Seguir el ejemplo de la aristocracia significaba renegar del trabajo. Mateo Luján expresa al respecto: "Los que tienen por deshonra el oficio mecánico, por cuya causa hay tantos holgazanes y malas mujeres, demás de los vicios que a la ociosidad acompañan por la vanagloria de los vestidos y no trabajar, hacen grandes faltas en sus casas..." (SGA, p. 657). Desde esta perspectiva, el ocio de aristócratas, plebeyos y mendigos fingidos ocasionaba la desintegración de la república. Dice Luna en su segundo Lazarillo que "Los trabajos humillan y la prosperidad ensoberbese", cuando el español tiene un real, y aunque no lo tenga, "desciende de los godos" y "no dará a torcer su brazo ni se estimará en menos que el más preciado, y morirá antes de hambre que ponerse a un oficio..." (LM, p. 130). En La garduña, Jaime, último marido de Rufina, siendo hijo de un alpargatero no quiere agotarse con el oficio ( $L g S$, p. 340); prefiere la mendicidad fingida, de la cual la narrativa picaresca da buena cuenta. Justina proporciona un ejemplo de los extremos a que se había llegado cuando se refiere a los hidalgos como mendigos fingidos: “¡Ay, hermanito, cuántos hidalgos honrados hay que en achaque que piden para pobres envergonzantes piden sin vergüenza para sí!” (LpJ, p. 299). Empero, el trabajo es

27 Retrato del peccador dormido, Salamanca, 1575, ff. 80-117 (BNMadrid, R. 25427).

28 Noticia general para la estimación de las artes, Madrid, 1600, p. 290 (BNMadrid, R. 28056).

${ }^{29}$ SAAVEdRa Fajardo, Idea de un príncipe político-cristiano, BAE, t. 25, p. 196.

${ }^{30}$ Op. cit., p. 108.

${ }^{31}$ Cellorigo, op. cit., f. 15.

32 Los bienes del honesto trabajo y daños de la ociosidad en ocho discursos, Madrid, 1614, f. 8 (BNMadrid, R. 7706). 
considerado fuente de virtud como el ocio de los vicios. Guzmán sostiene: "al bien ocupado no hay virtud que le falte, al ocioso no hay vicio que no le acompañe" ( $G A$, t. 2 , p. 82 ), por tanto "ni cumple la persona con lo que debe, cuando no trabaja, pues nació para ello y dello se ha de sustentar..." (GA, t. 4, p. 14).

La deshonra no sólo afectaba el trabajo manual sino también el comercio. Fray Luis de León considera que hay tres tipos de vida: la labranza, la contratación y la renta. Aunque reconoce la mercadería como un trabajo, establece una diferencia en la ganancia con la agricultura "porque la recoge de las haciendas agenas, y las más vezes con desgusto de los dueños dellas, y pocas vezes sin alguna mezcla de engaño. Y assí quanto a esto tiene algo de peligro, y es menos bien reputada"33. La ocupación industrial no estaba exenta de este tipo de prejuicios. La promulgación de la ley sobre las fábricas del reino, hecha por Carlos II ya muy entrado el siglo XviI, en 1682, es muestra de ello. El rey, conocedor de la decadencia de la industria, sostiene que no es contra nobleza tener fábricas de paños siempre y cuando "no hayan labrado ni labren en ellas por sus propias personas"34.

La racionalización de la economía ${ }^{35}$, es decir, la medición de ingresos y egresos, el cálculo, la medida y el ahorro que impuso el mercantilismo, se oponían a las concepciones aristocráticas sobre la liberalidad ${ }^{36}$ - cualidad de pechos nobles-, el honor y el ocio. No es extraño, pues, que surgiera una opinión general sobre los negociantes que los considerara avaros, mezquinos, codiciosos y prácticamente culpables de la situación del reino. La crítica a los procedimientos mercantiles era cotidiana, teólogos, economistas, procuradores de cortes y hasta el rey los censuran. Luis Saravia de la Calle puntualiza que en las contrataciones hay "muy gran engaño en las compras, y en las ventas y en la usura y en los empréstitos"37. En una premática de 1621 se dice de los criadores y tratantes que “...como dueños de las mercaderías se han hecho árbitros de los precios, subiéndolos de una semana a otra, sin causa suficiente que para ello ayan tenido, de que ha resultado la carestía de los jornales, y mantenimientos..."38.

33 La perfecta casada, The University of Chicago Press, Chicago, 1903, p. 33.

34 Novísima recopilación, Códigos españoles, Madrid, 1850, t. 24, lib. 8, 1.1, p. 142.

35 Véase José Antonio Maravall, op. cit., t. 2, pp. 75-80 y La cultura del Barroco, Ariel, Barcelona, 1975, pp. 351, 378.

36 BAPTISTA Remiro DE NAVARRA opina: "es la liberalidad la Gloria más grande, la más gloriosa grandeza de un ánimo heroyco, con todas las prendas sin ella es nada, sin todas las partes con ella es mucho" (Los peligros de Madrid, Zaragoza, 1646, ff. 2930 [BNMadrid, R. 4274]).

37 Instrucción de mercaderes, Madrid, 1949, p. 45.

38 Premática que su Magestad mandó publicar sobre la reformación de las causas de la carestía general en estos Reynos, y moderación en los precios de las mercaderías, y mantenimientos, salarios y jornales, Madrid, 1621 (AHN, Osuna, Leg. 2252, núm. 15). 
El espíritu de lucro, el afán de enriquecimiento, característicos del mercantilismo, fueron considerados un pecado capital de los negociantes. Escribe Andrés a su hermano Simón Ruiz: "Creo que no te contentarías con poseer todos los tesoros del mundo"39. Hay, pues, ciertas actitudes de los mercaderes, muchas dependientes de la racionalización de la economía, que llevan a la opinión pública a considerarlos miserables y codiciosos. Sin embargo, esto revela un trasfondo ideológico: las nuevas concepciones (paternidad colectiva, importancia del trabajo, valor de mérito) y necesidades económicas (racionalización de la economía) se oponen al pensamiento dominante (otium cum dignitate y nobleza basada en la herencia biológica y el recuerdo de las hazañas de los antepasados).

En la novela picaresca los hombres dedicados a los negocios, ya como grandes prestamistas, ya como pequeños comerciantes, tienen una participación notoria, básicamente en dos sentidos: una visión negativa, crítica de ciertas prácticas reprobables del comercio y las finanzas; y una visión positiva respecto al ejercicio lícito de dichas actividades. Esta narrativa, más que retomar las concepciones aristocráticas, hace una crítica desde la perspectiva reformista: por un lado, se censuran ciertas actitudes de los negociantes y determinados procedimientos comerciales que empañaban no sólo su imagen, sino una realización adecuada de su oficio; por otro, se invita a hacer un buen uso del comercio y se le reivindica.

La picaresca da buena cuenta de la especulación, las mohatras, las ventas fraudulentas, la alteración de los precios: Justina mojaba la lana antes de venderla para aumentar su peso (LpJ, p. 401); Estebanillo engañaba para mejorar las ganancias -en la escuela vendía polvos de romero como anacardina, agua del pozo por agua de la Alameda, cosméticos hechos por él como importados, carne de caballos muertos en batalla como carne fresca (EG, t. 1, pp. 64, 181; t. 2, p. 240)-; Mateo Luján decía que los comerciantes que acuden a los lugares multitudinarios van "queriendo enriquecerse en cuatro días", y señalaba los resultados del acaparamiento de productos por unos cuantos: "hacen entre sí alianza de los precios, y so color de hermandades y cofradías, que son muy santas, se comunican todos juntos, y se hacen jueces de las tasas" (SGA, p. 669) ${ }^{40}$; y declaraba Guzmán:

Quién y cuántas veces me oyeron y dije: "Prometo a v. Md. Que me tiene más de costo y no gano un real en toda la partida y, si la doy barato, es porque tengo de dar unos dineros para..."Y daba otras causas, no habiéndolas para ello más de querer ganar a ciento por ciento de su mano a la mía (GA, t. 5, pp. 109-110).

${ }^{39}$ Henri Lapeyre, Une famille de marchands: les Ruiz, Librairie Armand Colin, Paris, 1955, p. 74; la traducción es mía.

${ }^{40}$ Véase, también, $G A$, t. 5, pp. 109-110. 
Por otra parte, las bancarrotas eran comunes en la época. Los mercaderes al por mayor se quejaban de que no se castigara debidamente a los pequeños comerciantes cuando "se alzaban" y ocultaban sus bienes:

...como los mercaderes de por menor, de ordinario no tienen caudal con qué comprar de contado, y se les venden las mercaderías al fiado, obligándose a pagarlas a plazos hazen con esto grandes tiendas, y demostración de mucho caudal, y quando les parece que les puede estar bien (aunque tengan mucha hazienda y con qué pagar) ocultan sus bienes, y ponen las obligaciones de lo que se les deve en cabeça de terceros, y trazan una forma de quiebra, y se retraen en casas de Embaxadores, donde es imposible sacallos... ${ }^{41}$.

El padre de Guzmán se alzó dos o tres veces, sobre lo cual comenta Alemán: "Estratagemas son de mercaderes, que dondequiera se practican, especialmente en España, donde lo han hecho granjería ordinaria” (GA, t. 1, p. 58). El padre de Teresa de Manzanares era buhonero y pidió fiado a un mercader francés con quien tenía buen crédito, pero luego se fingió robado por más de tres mil reales ( TM, p. 228). Octavio Filuchi, en La garduña, se escondió con sus bienes cuando le fallaron las correspondencias. Estas quiebras ocasionaban, como es lógico, pérdidas en cadena, pues el comercio y los préstamos implicaban una red de relaciones.

Debido a la conducta avariciosa de algunos mercaderes, estos se vuelven objeto de múltiples burlas. A manera de fabliellas ${ }^{42}$, relacionadas con el sentido general de las novelas, se relatan historias donde hay un engañador, que generalmente es el pícaro, y un burlado, que es un mercader. En el Guzmán de Alfarache, el pícaro, ayudado por Aguilera, quien trabajaba con un mercader y tenía acceso al libro de Memorias, escribe en un blanco haber entregado cierta cantidad al mercader y coloca señales en la bolsa del dinero, de suerte tal que lo obliga a darle públicamente el supuesto dinero depositado. Debido al aislamiento en que vive el comerciante y a su comportamiento miserable sufre el desprecio social, situación que sirve para justificar la burla (GA, t. 4, cap. 6). En El Buscón, el móvil del engaño es otro. Un riquísimo mercader, pero avaro, es vejado con el fin de provocar hilaridad: se quitan las alcorzas a una caja, la llenan de palos y defecan sobre éstos; introducen estopa y lana en su bota de vino y, finalmente, colocan una piedra sobre el gabán para dificultar que el mercader se incorpore.

${ }^{41}$ Memorial de mercaderes al por mayor, s.l., s.a., (BNMadrid, R. 210-61).

${ }^{42}$ Cf. Alan Soons, Haz y envés del cuento risible en el Siglo de Oro, Artes Gráficas Clavileño, Madrid, 1976, p. 10. 
Nadie más insistente respecto a la burla económica a los mercaderes que Castillo Solórzano en La garduña de Sevilla, obra donde aparecen tres personajes relacionados con los negocios cuya característica es la mezquindad. Hay una relación orgánica entre los tres casos y podríamos considerarla como un "cuento tríptico"43. El primer mercader es Lorenzo Sarabia, agente de negocios de un perulero, de quien se dice que "tenía sus puntas de indiano en lo guardoso" ( $\mathrm{LgS}$, p. 192). Marquina es un hidalgo montañés que comenzó siendo criado de un mercader sevillano para terminar como poderosísimo tratante en las Indias. Su codicia lo lleva a ayunar con el objeto de "ahorrar, con que tenía mucha cantidad de dinero" ( $L g S$, p. 203). El tercero es Octavio Filuchi, mercader en grueso de origen genovés, "un poco codicioso y aun si mucho dijéramos hablaríamos con más propiedad" ( $L g S$, p. 253). Cualquiera que sea el trato o el origen del personaje todos coinciden en su avaricia, de ahí que sean estafados usando como anzuelo el erotismo, tal como vimos en La hija de Celestina con el genovés y el judío.

La crítica al mercader llega a puntualizar el mal uso de las finanzas cuando se muestran algunos procedimientos engañosos: la especulación en los cambios, los préstamos con altos intereses. El padre de Guzmán, por ejemplo, se dedica a "cambios y recambios" que, aunque son aceptados, se consideran producto de "nuestros pecados" dado que hay operaciones ilícitas. Dice Guzmán:

No quiero yo loar, ni Dios lo quiera, que defienda ser lícito lo que algunos dicen, prestar dinero por dinero, sobre prendas de oro o plata, por tiempo limitado o que se queden rematadas, ni otros tratillos paliados ni los que se llaman cambio seco ni que corra el dinero de feria en feria, donde jamás tuvieron hombre ni trato, que llevan la voz de Jacob y las manos de Esaú y a tiro de escopeta descubren el engaño $(G A, \mathrm{t}$. 1, pp. 54-55).

El inicio de cualquier trato requería buen crédito y caudal, sin embargo, en Castilla se había hecho un uso general de las contraescrituras. Guzmán las practica y describe el procedimiento:

Todas aquellas veces que el mercader pobre se quiere meter a mayor trato, pide para su crédito a un su pariente o amigo le dé algún juro de importancia o hacienda de confianza. De lo cual hace contraescritura, en que confiesa que, no obstante que aquello parece suyo, real y verdaderamente no lo es y que se lo volverá siempre, cada y cuando que lo pida. Con esto halla quien le fíe su hacienda (GA, t. 4, p. 228). 
La incertidumbre del crédito llevaba a la pérdida de confianza, lo cual iba en detrimento de las actividades comerciales y crediticias. Los procedimientos fraudulentos no permitían un ambiente de seguridad en los tratos ni entre los mismos negociantes ni en la población que cada vez que hacía una operación se sentía engañada. En consecuencia, se consideraba inmorales a quienes las realizaban. De los genoveses en el Guzmán se dice que "traían las conciencias en faltriqueras descosidas, de donde se les pierde y ninguno la tiene" (GA, t. 2, p. 216); y Quevedo los llama "Antecristos de las monedas de España" ( $E B$, p. 160). Una idea similar expresa del comerciante:

Y todo lo juraba por su conciencia, aunque yo pienso que conciencia en mercader es como virgo en cantonera, que se vende sin haberle. Nadie casi tiene conciencia de todos los deste trato, porque como oyen decir que muerde por muy poco, han dado en dejarla con el ombligo en naciendo (EB, p. 161).

Esta ausencia de valores era considerada uno de los mayores pecados, debido a ella Dios enviaba castigos tan severos como la peste ${ }^{44}$. Dado que iba en contra del bienestar y la prosperidad del reino, debería ser extirpada ${ }^{45}$. Esta imagen negativa del mercader parecería apoyar la tesis de Maurice Molho sobre el carácter anticapitalista de la picaresca, dado que, desde su concepción, esta narrativa se manifiesta en contra de la alienación de los valores mercantiles vistos como antítesis de la nobleza. A partir de la consideración del pícaro como encarnación del antihonor, producto del determinismo hereditario que "constituye de algún modo la hipótesis de toda filosofía picaresca", Molho define al Guzmán como "una violenta requisitoria anticapitalista" 46 . Respecto al determinismo ya vimos las ideas sobre la paternidad colectiva de Adán en la que se basa el estamento burgués, veremos ahora que esta narrativa también muestra otra visión del mundo de los negocios.

Las soluciones para la restauración de España varían, pero destaca la insistencia en la necesidad de fomentar el comercio. El declive castellano era evidente y Felipe IV tenía plena conciencia de "que el [comercio] destos Reynos [iba] cada día en disminución..." ${ }^{7}$. En

${ }^{44}$ Actas de las Cortes de Castilla, 17 de noviembre de 1607, Madrid, 1915, t. 23, p. 602.

45 Cf. Cellorigo, op. cit., f. 56; los procuradores de cortes dicen: "La principal causa de la necessidad en que vive mucha gente destos Reynos, entendemos que son los excessos que en ellos ay de Moatras, Vsuras y Tablagerías, y el poco cuydado que los Corregidores tienen en castigarlo con el rigor que las leyes mandan" (Capitulos generales de las Cortes [1592-1598], 1604, f. 20 [BNMadrid, R. 22472]).

${ }^{46}$ Introducción al pensamiento picaresco, Anaya, Madrid, 1972, pp. 24 y 67, respectivamente.

47 Premática y ley que su Magestad ha mandado promulgar, y que se guarde, en razón del comercio y nuevo Consulado, 9 de febrero de 1632, Madrid (BNMadrid, VE. 39-34). 
palabras de Saavedra Fajardo: "Una honra inmortal le espera a vuestra alteza si favoreciera y honrare el trato y la mercancía..."48. Por ello, Cellorigo ${ }^{49}$ y Saavedra Fajardo invitan a los nobles a practicar la mercadería por terceras personas; los procuradores de las cortes piden que no se abandone; políticos, economistas y mercadere ${ }^{50}$ hacen hincapié en su necesidad y ventajas. Los hombres de negocios españoles preferían las operaciones financieras, la especulación monetaria y las rentas dado que no corrían los riesgos del comercio. Una lectura de las Actas de las Cortes de Castilla ${ }^{51}$ permite ver que dichas actividades iban en aumento. De ahí que la picaresca también se encargue de reivindicar el buen uso del comercio, la ética de los negocios, como insistían los pensadores reformistas.

Damián de Olivares piensa que uno de los mayores daños al comercio "es desestimarle en España, deshonrándose con él, y despreciando a los que le usan, para cargos honrosos, hábitos y otros oficios" 52 . El menosprecio social de los mercaderes y el comercio podemos verlo en Trapaza donde, en la segunda novela intercalada, un príncipe de Salerno se hace pasar por mercader veneciano. Lucendra, hija del duque de Calabria lo tutea y luego lo hace su secretario: "que era sobrada ocupación a su poca calidad y suficiencia". Este texto es bastante ilustrativo en lo que se refiere a los ejercicios impropios para los hombres de negocios. Cuando el mercader desea participar en un torneo, dice el narrador: "Mucho gusto recibió Lucendra de oírle esto, porque ya en ello descubría su ilustre sangre, pues era cierto que siendo mercader no se levantaran los pensamientos a tal ejercicio, propio de los caballeros generosos". Salta a la vista la posición relegada de los mercaderes en la sociedad aristocráticoseñorial, pues además la dama le habla de usted cuando descubre la identidad del personaje. El mercader es colocado en la base de la pirámide estamental y no tiene derecho a vestir bien, ya que la "República pone la mira de su buen gobierno en que ninguno de ella traiga costosos trajes, principalmente la gente de pueblo, como él había fingido ser...”. El personaje, consciente de su poca calidad, confiesa que fuera de su patria "por lo menos por mi porte quiero ser tenido en más que mercader" (AbT, pp. 206-208). Sin embargo, a pesar de su aparente posición inferior, es digno de confianza, pues se le admite en la noble casa.

48 SaAvedra Fajardo, op. cit., p. 187.

49 Op. cit., f. 32.

${ }^{50}$ Véanse algunos ejemplos en Actas de las Cortes de Castilla, 1607, Madrid, 1915, t. 23, p. 22; 1610, t. 25, pp. 709-710; 1615, t. 27, p. 33; Gerónimo de Zevallos, Arte Real para el buen gobierno de los Reyes y Príncipes, y de sus vassallos, Toledo, 1623 (BNMadrid, R. 27402); Fernández de NAVARRete, Conservación de monarquías, BAE, t. 25, p. 472; D. De Olivares, Respuesta..., f. 4.

${ }^{51}$ Véase, por ejemplo, 5 de marzo de 1603, t. 21, p. 397.

52 Memorial, Toledo, 1624, f. 4 (BNMadrid, VE. 209-158). 
En Teresa de Manzanares, como vimos, aparece un buhonero que se finge en quiebra y se queda con tres mil reales: "Con éstos se halló en su poder el gabacho, habidos con tan poca conciencia por conocer la bondad del que le fió" (TM, p. 228). Estas palabras permiten ver dos aspectos de los negociantes: la poca conciencia del estafador, por un lado, y la buena fe del estafado. Por otra parte, el comportamiento mezquino del negociante encuentra justificación dada la dificultad que implica reunir el dinero. Como otros autores, Castillo Solórzano critica la mezquindad, pero la amplía a cualquier estamento y la justifica cuando la riqueza adquirida ha sido producto del trabajo. Así, el hidalgo bastardo que llega de las Indias a Málaga, cuando hereda tres mil ducados de renta del suegro: "Era hombre muy miserable, de la data de muchos que vienen de Indias; pero éste no tenía la causa por qué serlo, porque las haciendas de los indianos ganadas con trabajo obligan a ser bien guardadas, y esto les hace ser miserables..." (TM, p. 295). Teresa se casa en Sevilla con un perulero que "era la misma miseria, plaga que traen todos los que pasan de España a ganar hacienda a las Indias, que como allá les cuesta trabajo el adquirirla, así la guardan” (TM, p. 370). La adquisición de riquezas mediante el ejercicio laboral propicia el ahorro, mientras que la hacienda adquirida fácilmente inclina a la dilapidación o incluso también a la mezquindad. En Trapaza, por ejemplo, aparece un caballero que no tiene criado y alimenta a su caballo para ahorrar; luego se presenta un noble avaro al que se le componen unos versos satíricos (AbT, pp. 248-252). Castillo Solórzano critica, en La garduña, lo generalizado de la codicia. Recordemos que en la burla a Octavio Filuchi, Garay finge conocer el secreto de la piedra filosofal y declara no haberlo hecho público dada la necesidad económica del rey debida a las guerras, pues aunque estaría dispuesto a hacerlo un par de veces, señala que "la codicia de los hombres es tal que no se contentan con lo que tienen, aunque sea mucho, sino que anhelan siempre tener más" ( LgS, p. 260). No es pues privativo de los negociantes un comportamiento vicioso, sino que toca a toda la naturaleza humana, empezando por el rey. Esta censura era común: Bartolomé Leonardo de Argensola, por ejemplo, afirma que "la enfermedad de la Corte son vicios de mala calidad y lo que más parese que se señalan, cudicia, rapiña, y deshonestidad escandalosa en todos géneros de gente..."53. Asimismo, no faltaban pensadores que aconsejaran al príncipe evitar gastos superfluos y seguir las reglas, absolutamente necesarias, de los negociantes. Juan de Mariana sostiene que "Nues-

53 "De cómo se remediaran los vicios de la Corte y que no acuda a ella tanta gente inútil”, Libro de varias cosas en prosa, de hombres insignes en letras y política y de Raçón de Estado, s.l., s.a., f. 125 (BNMadrid, ms. 8755). 
tro cuidado principal y mayor debe consistir... en que estén nivelados los gastos con los ingresos" 54 .

La narrativa picaresca reivindica la figura del mercader al caracterizarlo como un hombre que no sólo sigue las normas del buen comercio, sino que también tiene un comportamiento virtuoso. Pedro de la Trampa, padre de Trapaza, trabajaba como pelaire para un mercader en cuya fábrica conoció a Olalla y la dejó encinta. El padre de ésta habló con su amigo, el mercader, quien dijo a Pedro: "que él le ofrecía de su parte no faltarle jamás mientras viviese, y demás de esto ayudarle para su casamiento en todo cuanto pudiese, por la afición grande que le había cobrado" (AbT, pp. 135-136). Además de caritativo, fiel a la amistad y a la justicia, se describe al personaje como "buen cristiano" que premia el trabajo, pues hace capataz a Pedro por ser un buen trabajador. Por otra parte, el genovés asentista del rey, con quien se casa Estefanía, su sirvienta, es un hombre bondadoso que ama a su mujer y le hereda quince mil ducados (AbT, p. 304).

En Teresa de Manzanares, el perulero don Álvaro es un "hidalgo de lo mejor de Navarra" con ideas respecto al honor como cualquier noble. Además, como hombre de negocios, cumple con sus obligaciones puntualmente y por adelantado. A don Sancho, galán de Teresa, le llega una letra de Madrid remitida a don Álvaro "y aunque venía el plazo de la paga de ella a diez días vista, él se la pagó luego sin ir a casa, cosa que estimó en mucho don Sancho, y desde allí quedaron muy grandes amigos..." (TM, p. 376). Es revelador que el negociante proceda de Navarra, pues ello indica que el linaje no es del todo incompatible con la actividad mercantil, tal como sabemos que ocurría en Sevilla ${ }^{55}$. Salta a la vista que los mercaderes de Castillo Solórzano no corresponden a la imagen arquetípica que se había conformado.

Para Maurice Molho, como vimos, esta narrativa se opone al mercantilismo, dado que se manifiesta contra el espíritu de lucro y considera la posesión de dinero contraria a la virtud nobiliaria. Asimismo, el crítico refuerza esta idea en el hecho de que, en su inestabilidad ocupacional, algunos pícaros son comerciantes. En efecto, Guzmán, Justina, Lazarillo de Manzanares, Rufina, Teresa y Estebanillo se dedican a los tratos y, salvo Justina, los demás realizan estas actividades al final de las obras. El protagonista del Lazarillo de Manzanares anuncia, desde los capítulos iniciales, su deseo de pasarse a las Indias "donde hombres baxos vienen de ordinario ricos, aunque vayan sin oficio, porque llevando consigo el poderse aplicar a mercaderes de cosas baxas, nunca vienen sin dineros" ( $L M$, t. 1, p. 38). La mercadería se presenta como una posibilidad laboral necesaria que

54 Op. cit., p. 548.

55 Sobre este tema véase Ruth Pike, Aristócratas y comerciantes, Ariel, Barcelona, 1978. 
puede ejercer cualquier individuo, sea cual sea su genealogía o extracción social. A diferencia de otros pícaros, Lázaro tiene muy claro su objetivo y la obra culminará cuando realice su aspiración. En opinión de Giuseppe Sansone ${ }^{56}$, el viaje a las Indias, última aventura del personaje, es innecesaria. No obstante, dentro de la estructura narrativa hay un lazo de unión que se inicia en las primeras páginas y atraviesa el resto de la obra. Para empezar, la familia adoptiva de Lázaro se dedica al comercio de telas y otros objetos; el protagonista repetirá, en varias ocasiones, su deseo de ser mercader en las Indias, lo comenta, por ejemplo, con el ermitaño, quien le aconseja desistir de su intento. Cuando huye de quienes quieren casarlo se topa con "un hidalgo de Sevilla, rico y poderoso en ella", cuyo hijo fue su discípulo, y que se presenta como benefactor y protector del pícaro pues le está muy agradecido: "En mi posada estaréys regalado y servido sin que os cueste un quarto, ansí la comida como el juntarle los processos [al acusador] que en Granada, Málaga y otras partes tiene" ( $L M$, t. 1, p. 141). El hidalgo se dedica a la exportación de mercancías a las Indias y ofrece a Lázaro la posibilidad de cumplir su objetivo. El mercader hidalgo funciona como contraste respecto a la idea de que la ocupación mercantil no era para los nobles, sus valores son otros, se trata de un hombre virtuoso al que no le importa la genealogía del pícaro. El comercio, en este contexto, es un trabajo digno para cualquier miembro de la sociedad.

La picaresca presenta, pues, personajes con las cualidades del buen mercader especificadas en El primer manual hispánico de mercadería del siglo $\mathrm{XI}^{57}$ : dignos de confianza, caritativos, cristianos, justos y, sobre todo, que hacen buen uso del comercio. Incluso, aunque en España se desea limitar las operaciones cambiarias, encontramos su lado positivo en el Guzmán:

Mas, lo que absolutamente se entiende por cambio es obra indiferente, de que se puede usar bien y mal y, como tal, aunque injustamente, no me maravillo que, no debiéndola tener por mala, se repruebe. Mas la evidentemente buena, sin sombra de cosa que no lo sea, que se murmure y vitupere, eso es lo que me asombra (GA, t. 1, p. 55).

La censura está dirigida a la falta de ética en las operaciones, no a las actividades en sí. Esto indica que el empleo de la riqueza determina la calidad de sus poseedores: ni el comercio, los cambios o el dinero son malos en sí. Cuando Rufina roba ocho mil escudos a Marquina todos se alegran en La garduña:

${ }^{56}$ En su introd. al Lazarillo de Manzanares, ed. cit., p. xxx.

${ }^{57}$ Miguel Gual Camarena, El primer manual hispánico de mercadería. Siglo XIV, CSIC, Barcelona, 1981. 
...por verle tan cudicioso y poco amigo de hacer bien a nadie, que aun con ser interés suyo y en bien de su alma, pocas veces lo vieron hacer alguna limosna. Escarmienten en éste los avaros, considerando que si Dios les da bienes es para que con ellos aprovechen al prójimo y no sea su ídolo su dinero ( $\mathrm{LgS}$, p. 224).

No es, pues, la mercadería como trabajo remunerativo lo criticado, sino la conducta de los individuos ante la posesión de bienes: el dinero debía circular y una forma de hacerlo era la caridad. Si tenemos en cuenta que en esta obra los mercaderes no son mezquinos en su vida personal, veremos más clara esta idea de reforma. De la casa de Octavio Filuchi se dice que tiene pinturas, láminas de Roma, escritorios, pabellones costosos, libros, agnusdeyes, etc. (cf. LgS, p. 154). Y exactamente lo mismo ocurre en la casa Marquina donde tiene "muy buenas colgaduras de verano, frescas sillas de vaqueta de Moscovia, curiosos bufetes y escritorios de ébano y marfil, que aunque miserable, no lo era para el adorno de sus piezas..." (LgS, p. 207). Nada más claro que un texto de Guzmán sobre la riqueza:

La riqueza de suyo y en sí no tiene honra, ciencia, poder, valor ni otro bien, pena ni gloria, más de aquella para que cada uno la encamina... Ni se condena el rico ni se salva el pobre por ser el uno pobre y el otro rico; sino por el uso dello... [Dios] Hizo poderosos y necesitados. A ricos dio los bienes temporales y los espirituales a los pobres. Porque, distribuyendo el rico su riqueza con el pobre, de allí comprase la gracia y, quedando ambos iguales, igualmente ganasen el cielo ( $G A$, t. 4, pp. 174-175).

La caridad, pues, se presenta como una forma de hacer circular la riqueza, como ha demostrado Michel Cavillac respecto al Guzmán de Alfarache y que aquí vemos sucintamente. Tal como proponía el neoestoicismo senequista (con estrechas relaciones con el erasmismo), del cual da buena cuenta Quevedo en sus obras y en su relación epistolar con Justo Lipsio - cuyas obras figuran en la biblioteca del conde-duque de Olivares ${ }^{58}$-, debía haber una reforma que partiera del interior del individuo. De ahí la propuesta de Guzmán: "El mozo que tratare de querer ser viejo, deje mis pasos y trate de vencer pasiones. Dispóngase a el [sic] trabajo y a fuerza de su voluntad ríndala[s] en el suelo, venciendo viejos deseos... gastando el tiempo en virtuosos ejercicios..." ( $G A$, t. 3, p. 252). Vencerse a sí mismo y ser un hombre nuevo llevaba a un cambio social axiológico que repercutiría en todos los campos de acción de la España del siglo XVII.

${ }^{58}$ Véase John H. Ellıot, Spain and its world, 1500-1700, 2nd ed., Yale University Press, New Haven-London, 1989, p. 200. 
El carácter reformista de la picaresca, que se muestra desde los prólogos, es evidente al hacerse portavoz de un pensamiento renovador acorde con las circunstancias que atravesaba la Península: proclama la igualdad fundada en la universalidad del pecado original, lo que implicaba la ponderación de la virtud, el mérito y el trabajo, con una reivindicación fundamental del buen uso del comercio, frente al linaje y el ocio de la aristocracia.

YSLA CAMPBELL

Universidad Autónoma de Ciudad Juárez 
